\title{
Contribution of the non-effector members of the HrpL regulon, iaaL and matE, to the virulence of Pseudomonas syringae pv. tomato DC3000 in tomato plants
}

\author{
Melissa G. Castillo-Lizardo ${ }^{1,2 \dagger}$, Isabel M. Aragón ${ }^{1 \dagger}$, Vivian Carvajal ${ }^{3}$, Isabel M. Matas ${ }^{1,4}$, María Luisa Pérez-Bueno ${ }^{3}$,
} María-Trinidad Gallegos ${ }^{3}$, Matilde Barón ${ }^{3}$ and Cayo Ramos ${ }^{1^{*}}$ (D)

\begin{abstract}
Background: The phytohormone indole-3-acetic acid (IAA) is widely distributed among plant-associated bacteria. Certain strains of the Pseudomonas syringae complex can further metabolize IAA into a less biologically active amino acid conjugate, 3-indole-acetyl- $\varepsilon$-L-lysine, through the action of the iaaL gene. In $P$. syringae and Pseudomonas savastanoi strains, the iaal gene is found in synteny with an upstream gene, here called matE, encoding a putative MATE family transporter. In P. syringae pv. tomato (Pto) DC3000, a pathogen of tomato and Arabidopsis plants, the HrpL sigma factor controls the expression of a suite of virulence-associated genes via binding to hrp box promoters, including that of the iaaL gene. However, the significance of HrpL activation of the iaaL gene in the virulence of Pto DC3000 is still unclear.

Results: A conserved hrp box motif is found upstream of the iaaL gene in the genomes of $P$. syringae strains. However, although the promoter region of matE is only conserved in genomospecies 3 of this bacterial group, we showed that this gene also belongs to the Pto DC3000 HrpL regulon. We also demonstrated that the iaaL gene is transcribed both independently and as part of an operon with matE in this pathogen. Deletion of either the iaaL or the matE gene resulted in reduced fitness and virulence of Pto DC3000 in tomato plants. In addition, we used multicolor fluorescence imaging to visualize the responses of tomato plants to wild-type Pto DC3000 and to its $\Delta$ matE and $\Delta i a a L$ mutants. Activation of secondary metabolism prior to the development of visual symptoms was observed in tomato leaves after bacterial challenges with all strains. However, the observed changes were strongest in plants challenged by the wild-type strain, indicating lower activation of secondary metabolism in plants infected with the $\Delta$ matE or $\triangle i a a L$ mutants.
\end{abstract}

Conclusions: Our results provide new evidence for the roles of non-type III effector genes belonging to the Pto DC3000 HrpL regulon in virulence.

\section{Background}

The ability to produce the auxin phytohormone indole3 -acetic acid (IAA) is widespread among soil and plantassociated bacteria. As more bacterial species have been analyzed, the roles of auxins in bacterial interactions

\footnotetext{
*Correspondence: crr@uma.es

${ }^{\dagger}$ Equal contributors

'Área de Genética, Universidad de Málaga, Instituto de Hortofruticultura Subtropical y Mediterránea "La Mayora", Universidad de Málaga-CSIC (IHSM-UMA-CSIC), Campus de Teatinos, 29071 Málaga, Spain

Full list of author information is available at the end of the article
}

with plants appear to be diverse, varying from pathogenesis to phytostimulation [1]. The best-characterized IAA biosynthetic pathway in phytopathogenic bacteria is the indole-3-acetamide pathway. In this pathway, the genetic determinants involved in the conversion of L-tryptophan (Trp) to IAA are Trp monooxygenase (encoded by the iaaM gene), which converts Trp to indole-3-acetamide (IAM), and IAM hydrolase (encoded by the $i a a H$ gene), which catalyzes the transformation of IAM to IAA. These two genes have been cloned and characterized for phytopathogenic bacteria such as Agrobacterium spp.

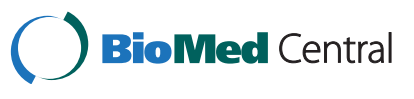


and Pseudomonas savastanoi $[2,3]$. P. savastanoi pv. nerii, the causal agent of oleander (Nerium oleander) knot disease, also converts IAA to indole-acetyl-e-L-lysine (IAALys), a less biologically active compound as estimated in a coleoptile elongation assay [4-6]. This conversion involves the enzyme IAA-Lys synthase, encoded by the iaaL gene [7-9]. Although most $P$. syringae pathovars produce detectable amounts of IAA in the presence of Trp [10], IAA synthesis usually involves different genes than iaaM and $i a a H$ [10-12]. In contrast, iaaL is widespread in P. syringae pathovars and is often found in plasmids $[7,10,13]$. Inactivation of the $i a a L$ gene by transposon mutagenesis in P. savastanoi pv. nerii resulted in the accumulation of IAA in the culture medium; however, this mutant did not cause typical knot symptoms, probably due to its inability to multiply within host tissues [8].

P. syringae pv. tomato (Pto) DC3000, which causes bacterial specks on tomatoes and can infect the model plants Arabidopsis thaliana and Nicotiana benthamiana, is an important model for the study of plant-pathogen interactions [14-16]. The ability of DC3000 to infect host plants depends on numerous genes expressed by the HrpL alternative sigma factor. The Pto DC3000 HrpL regulon includes genes involved in the hypersensitive response and others encoding the pathogenicity (Hrp) type III secretion system (T3SS) machinery, a repertoire of type III effector proteins [15, 17-19], as well as genes encoding factors unrelated to the T3SS, such as iaaL (PSPTO_0371) and the genes for coronatine synthesis [17-21]. A recent analysis of the role of the Pto DC3000 iaaL gene in the infection of $N$. benthamiana plants concluded that an iaaL deletion mutant did not exhibit phenotypic differences in terms of in planta growth, virulence, or hypersensitive response (HR) compared to the wild type strain [20]. Conversely, although the genome of Pto DC3000 encodes two coding sequences (CDS) that are likely involved in auxin production [14, 22], the roles of these genes in IAA biosynthesis have not been demonstrated yet [11]. Thus, the significance of HrpL activation of the iaaL gene in the virulence of Pto DC3000 is still unclear.

A reporter transposon screen for HrpL-activated genes in Pto DC3000 identified several genes, including iaaL, that were linked to novel variations of the canonical sequence for Hrp boxes [17] found in HrpL-dependent promoters [23]. Further analysis of the transposon mutants revealed that the upstream promoter-proximal ORF encoded a putative MATE (multidrug and toxic compound extrusion) family transporter gene (PSPTO_0370) [17]. Recently, overexpression of HrpL in Pto DC3000 was shown to induce the expression of this putative MATE transporter gene, suggesting that it is part of the Pto DC3000 HrpL regulon [18]. Efflux pumps associated with multidrug resistance (MDR) contribute to bacterial survival in plant tissues via the removal of antimicrobial secondary metabolites, such as flavonoids, isoprenoids, and alkaloids, which are present in healthy plant tissues or synthesized de novo in response to pathogen attack $[24,25]$. MDR efflux pumps have been shown to contribute to the colonization of host plants by bacterial phytopathogens, including $P$. syringae strains [26, 27]; however, little evidence has been found for the contribution of MATE transporters to the virulence of bacterial phytopathogens [28].

The aim of this study was to analyze the expression of the iaaL gene and of the putative MATE family transporter gene, hereafter called matE, located just upstream of iaaL, both in wild-type Pto DC3000 and in a knockout $\Delta h r p L$ mutant generated by gene replacement. The roles of these genes in the virulence of Pto DC3000 during infection of tomato plants was analyzed, not only in terms of the pathogen-induced symptomatology observed in tomato leaves but also prior to the development of symptoms. To analyze the pre-symptomatic responses of tomato plants to bacterial infection, we used multicolor fluorescence imaging (MCFI), a technique that allows visualization of the activation of plant secondary metabolism in response to pathogen infection.

\section{Methods}

\section{Bacterial strains, plasmids, and culture medium}

The bacterial strains and plasmids used in this study are listed in Table 1. Pto DC3000 and mutants were routinely grown in lysogeny broth (LB) medium $[29,30]$ at $28{ }^{\circ} \mathrm{C}$, and $E$. coli strains were grown at $37^{\circ} \mathrm{C}$. When appropriate, antibiotics were added to the medium at the following final concentrations (in $\mu \mathrm{g} / \mathrm{ml}$ ): for ampicillin, 100 (E. coli strains), 300 (Pto DC3000 strains in solid medium) and 150 (Pto DC3000 strains in liquid medium); for kanamycin, 50 (E. coli strains) and 25 (Pto DC3000 strains); for tetracycline, 10 .

\section{Preparation of total RNA}

RNA was extracted from cultures grown on M9 minimal media supplemented with $5 \mathrm{mM}$ mannitol $[30,31]$ and ferric citrate at $0.0006 \%$. The cells were pelleted at exponential phase, i.e., when they reached an optical density of 0.5 at $660 \mathrm{~nm}\left(\mathrm{OD}_{660 \mathrm{~nm}}\right)$. The pellets were processed for RNA isolation using TriPure Isolation Reagent (Roche Applied Science; Mannheim, Germany) according to the manufacturer's instructions with the following exceptions: the TRIPure was preheated to $65^{\circ} \mathrm{C}$, the lysis step was carried out at $65{ }^{\circ} \mathrm{C}$ and $\mathrm{BCP}$ (1-bromo-3-chloropropane) (Molecular Research Center; Cincinnati, OH, U.S.A.) was used instead of chloroform. The RNA concentration was determined spectrophotometrically, and its integrity was assessed by agarose gel electrophoresis. Total RNA was treated with a TURBO DNA-free ${ }^{\text {Tm }}$-Kit (Applied Biosystems; California, U.S.A.) as detailed by the manufacturer. 
Table 1 Strains and plasmids used in this work

\begin{tabular}{|c|c|c|}
\hline Strain/Plasmid & Genotype $^{a}$ & Reference \\
\hline \multicolumn{3}{|l|}{ P. syringae pv. tomato } \\
\hline DC3000 & Rif $^{r}$ & {$[14]$} \\
\hline$\triangle i a a L$ & $\mathrm{Km}^{\mathrm{r}}$ & This work \\
\hline$\triangle m a t E$ & $\mathrm{Km}^{\mathrm{r}}$ & This work \\
\hline$\Delta h r p L$ & $\mathrm{Km}^{\mathrm{r}}$ & This work \\
\hline \multicolumn{3}{|l|}{ E. coli } \\
\hline \multirow[t]{2}{*}{ E. coli DH5a } & F-, ф80dlacZ M15, (lacZYA-argF) U169, deoR, recA1, endA, & {$[66]$} \\
\hline & hsdR17 $\left(r k^{-} m k^{-}\right)$, phoA, supE44, thi-1, gyrA96, relA1. & \\
\hline \multicolumn{3}{|l|}{ Plasmids } \\
\hline pGEM-T Easy Vector & Ampr', ori f1, lacz & Promega, USA \\
\hline pGEM-T Vector & Ampr', ori f1, lacZ & Promega, USA \\
\hline pGEM-T-KmFRT-BamHI & Contains $\mathrm{Km}^{r}$ from pKD4 (Ampr $\mathrm{Km}^{r}$ ) & [67] \\
\hline pMP220 & Expression Vector, $T c^{r}$ & {$[35]$} \\
\hline pJB3Tc20 & Expression Vector, $T c^{r}$ & {$[68]$} \\
\hline plAC1 & pGEM-T derivative, contains approx. $0.5 \mathrm{~kb}$ on each side of the iaal gene (Amp') & This work \\
\hline pIAC2 & pGEM-T derivative, contains approx. $0.5 \mathrm{~kb}$ on each side of the $h r p L$ gene (Amp') & This work \\
\hline plAC3 & pGEM-T derivative, contains approx. $0.5 \mathrm{~kb}$ on each side of the mat gene (Ampr) & This work \\
\hline plAC1-Km & $\begin{array}{l}\text { pGEM-T derivative, contains approx. } 0.5 \mathrm{~kb} \text { on each side of the iaal gene interrupted } \\
\text { by the kanamycin resistance gene nptII }\left(\mathrm{Amp}^{r}, \mathrm{Km}^{\prime}\right)\end{array}$ & This work \\
\hline $\mathrm{plAC2}-\mathrm{Km}$ & $\begin{array}{l}\text { pGEM-T derivative, contains approx. } 0.5 \mathrm{~kb} \text { on each side of the hrpL gene interrupted } \\
\text { by the kanamycin resistance gene } n p t / l\left(\mathrm{Amp}^{r}, \mathrm{Km}^{r}\right)\end{array}$ & This work \\
\hline plAC3-Km & 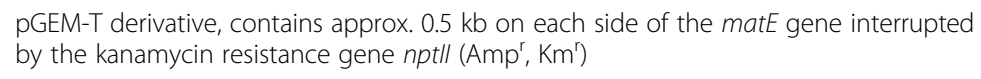 & This work \\
\hline pMP220-PmatE & pMP220 derivative, contains the lac $Z$ gene expressed from the $P_{\text {matE }}$ promoter $\left(T c^{r}\right)$ & This work \\
\hline pMP220-R2 & pMP220 derivative, contains the lac $Z$ gene expressed from the $\mathrm{P}_{\text {iaal }}$ promoter $\left(T c^{\prime}\right)$ & This work \\
\hline pJB3-matE & pJB3 derivative, contains the matE gene with RBS & This work \\
\hline pJB3-iaaL & pJB3 derivative, contains the iaaL gene with RBS & This work \\
\hline
\end{tabular}

${ }^{a} \mathrm{Amp}^{r}, \mathrm{Km}^{r}$, Rif' and $\mathrm{Tc}^{r}$ indicate resistance to ampicillin, kanamycin, rifampicin and tetracycline, respectively

Subsequently, the samples were tested for genomic contamination by PCR.

\section{Primer extension analysis}

DNA-free RNA, prepared as described above, was heattreated at $80^{\circ} \mathrm{C}$ for $5 \mathrm{~min}$. Subsequently, $30 \mu \mathrm{g}$ of RNA was annealed at $75{ }^{\circ} \mathrm{C}$ for $10 \mathrm{~min}$, and then the temperature was allowed to slowly decrease to $60{ }^{\circ} \mathrm{C}$ within $30 \mathrm{~min}$. Annealing was performed in a buffer containing $100 \mathrm{mM}$ $\mathrm{NaCl}$ and $50 \mathrm{mM}$ Tris- $\mathrm{Cl}$ at $\mathrm{pH}$ 7.5. The specific primers (Additional file 4: Table S1) and the $\phi X 174$ DNA/Hinfl dephosphorylated marker were labeled using $\left[\gamma^{32}-\mathrm{P}\right]$ ATP (3000 Ci/mmol) (PerkinElmer; Boston, USA) and T4 polynucleotide kinase, according to the manufacturer's instructions for the Primer Extension System-AMV Reverse Transcriptase (Promega; Madison, USA). Runoff reverse transcription reactions were performed for $1 \mathrm{~h}$ at $60{ }^{\circ} \mathrm{C}$ using 15 units of ThermoScript ${ }^{\mathrm{max}}$ RNase H- (Invitrogen; California, USA) in its provided buffer (complemented with $1 \mathrm{mM}$ of each dNTP and $5 \mathrm{mM}$ DTT). Reactions were stopped by the addition of one volume of loading dye (Promega; Madison, USA) and were analyzed on $6 \%$ polyacrylamide sequencing gels containing $8 \mathrm{M}$ urea. The results were visualized either using $\mathrm{X}$-ray films or exposure for $24 \mathrm{~h}$ to Imaging Plates (IP BAS-MP 2040S), which were analyzed with a Fujifilm-BAS 1500 (Fuji; Tokyo, Japan).

\section{Transcription initiation mapping by 5 'CRACE}

The transcription start site of $m a t E$ was determined using the 5'cRACE method [32-34]. cDNA synthesis was performed using total DNA-free RNA, obtained as described above. One microgram of this RNA was used as a template to synthesize first-strand cDNA using a SMART RACE cDNA Amplification synthesis kit (Clontech; California, USA), and a gene-specific primer was designed to anneal within the coding region of the gene (Additional file 4: Table S1). The reactions proceeded for $90 \mathrm{~min}$ at $42{ }^{\circ} \mathrm{C}$. Then, they were diluted 10 -fold in water, and $1 \mu \mathrm{l}$ of these dilutions were used as templates in $20-\mu$ PCR reactions. The PCR cycles were as follows: 
5 cycles for $30 \mathrm{~s}$ at $94{ }^{\circ} \mathrm{C} ; 3 \mathrm{~min}$ at $72{ }^{\circ} \mathrm{C} ; 5$ cycles for $30 \mathrm{~s}$ at $94{ }^{\circ} \mathrm{C} ; 30 \mathrm{~s}$ at $70{ }^{\circ} \mathrm{C} ; 3 \mathrm{~min}$ at $72{ }^{\circ} \mathrm{C} ; 25$ cycles for $30 \mathrm{~s}$ at $94{ }^{\circ} \mathrm{C} ; 30 \mathrm{~s}$ at $68{ }^{\circ} \mathrm{C} ; 3 \mathrm{~min}$ at $72{ }^{\circ} \mathrm{C}$. The amplification products were cloned into the $\mathrm{pGEM}^{\circ}-\mathrm{T}$ Easy Vector (Promega; Madison, USA) and sequenced.

\section{RT-PCR}

DNA-free RNA was reverse transcribed using random hexamers included in the iScript ${ }^{\mathrm{m}} \mathrm{cDNA}$ synthesis kit (BioRad; California, USA). Afterwards, PCR reactions were performed with $\mathrm{GoTaq}^{\circ}$ polymerase (Promega; Madison, USA) using $100 \mathrm{ng}$ of cDNA as a template and specific primers detailed in Additional file 4: Table S1. Products were analyzed by agarose gel electrophoresis.

\section{$\beta$-galactosidase activity assays}

$\beta$-galactosidase activity was measured from DNA fragments cloned into the expression vector pMP220 [35] using the methods developed [29] and modified previously [36]. In summary, cells carrying the plasmids were cultured in LB media supplemented with $10 \mu \mathrm{g} / \mathrm{ml}$ tetracycline. Grown cultures were harvested by centrifugation and washed three times with $0.9 \% \mathrm{NaCl}$. Finally, cultures were adjusted to an $\mathrm{OD}_{600 \mathrm{~nm}}$ of 0.5 and cultured in minimal media as described above [30,31].

To measure $\beta$-galactosidase activity, $200 \mu \mathrm{l}$ of each culture were lysed with $100 \mu \mathrm{l}$ of chloroform and $50 \mu \mathrm{l}$ of $0.1 \%$ SDS and were then mixed with $800 \mu \mathrm{l}$ of $\mathrm{Z}$ buffer $\left(40 \mathrm{mM} \mathrm{Na}_{2} \mathrm{HPO}_{4}, 40 \mathrm{mM} \mathrm{NaH} \mathrm{PO}_{4}, 10 \mathrm{mM} \mathrm{KCl}\right.$, pH 7.0 and $50 \mathrm{mM} \beta$-mercaptoethanol, added just before use). After mixing, samples were incubated at room temperature for $5 \mathrm{~min}$. Then, $200 \mu \mathrm{l}$ of $\mathrm{Z}$ buffer containing $4 \mathrm{mg} / \mathrm{ml}$ o-nitrophenyl- $\beta$-D-galactopyranoside (ONPG) were added. The samples were then incubated at room temperature for 30-60 min until they turned yellow. Afterwards, reactions were stopped with $500 \mu \mathrm{l}$ of $1 \mathrm{M}$ $\mathrm{Na}_{2} \mathrm{CO}_{3}$, and the absorbance was measured at 420 and $550 \mathrm{~nm}$. In addition, absorbance at $600 \mathrm{~nm}$ was measured in the initial culture. The enzymatic activity (in Miller units) was determined with the equation $\left[\left(\mathrm{A}_{420}-1.7^{\text {* }}\right.\right.$ $\left.\left.\mathrm{A}_{550}\right)^{*} 1000\right] /\left(\mathrm{V}^{*} \mathrm{~A}_{600}{ }^{*} \mathrm{t}\right)$ [29], where $\mathrm{A}_{\mathrm{XXX}}$ is the absorbance at 420,550 and $600 \mathrm{~nm}, \mathrm{~V}$ is the volume of the culture in $\mathrm{ml}$ and $\mathrm{t}$ is the time of the reaction in minutes.

\section{Generation of knockout mutants}

Plasmids pIAC1, pIAC2, and pIAC3 were generated to obtain $\triangle i a a L, \Delta h p r L$, and $\triangle m a t E$ mutant strains, respectively. DNA fragments of approximately $0.5 \mathrm{~kb}$ corresponding to $5^{\prime}$ and $3^{\prime}$ regions flanking the target gene were cloned into the pGEM-T Easy vector (Promega; Madison, USA). This fragment was generated with three rounds of PCR amplification using the method described by [37]. All plasmids were sequenced to verify the absence of mutations.
Following sequencing, plasmids were labeled with the nptII kanamycin resistance gene flanked by FRT (flippase recognition target) sites. The fragment containing this gene sequence was obtained from the plasmids pGEM-T-KmFRT-BamHI or pGEM-TKmFRT-EcoRI (Table 1). The fragments resulting from digestion were cloned into the BamHI or EcoRI sites of vectors derived from pGEM-T containing previously amplified fragments.

Plasmids pIAC1, pIAC2 and pIAC3 (Table 1) were transformed by electroporation into the Pto DC3000 strain. Transformants were selected on LB media supplemented with kanamycin $(15 \mu \mathrm{g} / \mathrm{ml})$. Replica plates of the resulting colonies were created in plates with ampicillin $(300 \mu \mathrm{g} / \mathrm{ml})$ to determine whether each transformant was the result of a single recombination event (integration plasmid, $A m p^{\mathrm{R}}$ ) or a double recombination event (allelic exchange, $A \mathrm{mp}^{\mathrm{S}}$ ). Southern Blot analysis using a sequence complementary to a target gene as a probe was used to confirm whether allelic exchange had occurred in the correct location of the genome and that only one copy of the construct was inserted.

\section{Virulence assays and symptom quantification in tomato plants}

Seeds of tomato plants (Solanum lycopersicum var. Moneymaker) were germinated and grown in a growth chamber with a $16 / 8 \mathrm{~h}$ light/dark photoperiod at $24 / 18{ }^{\circ} \mathrm{C}$ day/night and at $70 \%$ relative humidity. Bacteria were grown on LB agar plates for $48 \mathrm{~h}$ at $28{ }^{\circ} \mathrm{C}$ and resuspended in $10 \mathrm{mM}$ $\mathrm{MgCl}_{2}$ at an $\mathrm{OD}_{600 \mathrm{~nm}}$ of 0.5 , corresponding to about $10^{8}$ colony forming units (CFU) per ml. Further serial dilutions were carried out to obtain suspensions for inoculations with different doses. Four to 5-week-old plants were inoculated by infiltrating bacterial suspensions into the intracellular spaces. Infiltration was achieved by pressing the bacterial suspension against the leaf with a 2-ml syringe without the needle. The negative control plants were mock-inoculated with a $10 \mathrm{mM} \mathrm{MgCl}$ solution. Each plant was infiltrated in three leaflets of the same leaf, and the infiltrated (IF) area covered half of the midrib on the right side of the main vein. The other halves of those leaflets were analyzed as non-infiltrated (NIF) areas. The evolution of disease symptoms was recorded at 2, 4, 7 and 9 days postinoculation (dpi). Bacteria were recovered from the infected leaves using a $10-\mathrm{mm}$ diameter cork borer. Five disks $\left(3.9 \mathrm{~cm}^{2}\right)$ per plant were homogenized via mechanical disruption in $1 \mathrm{ml}$ of $10 \mathrm{mM} \mathrm{MgCl}$, and the CFU per $\mathrm{cm}^{2}$ were counted by plating serial dilutions on LB plates with corresponding antibiotics. Quantification of necrotic lesions was performed at 9 dpi using the image analysis software Visilog 6.3 (Noesis; Courtaboeuf, France). Data were represented as the ratios of necrotic lesions per total leaf area. 


\section{Competition assays in tomato plants}

Competition assays were performed by mixing cultures of mutants and wild-type strains with an $\mathrm{OD}_{660 \mathrm{~nm}}$ of 0.5 in a 1:1 ratio. Four to 5-week-old tomato plants were inoculated with $5 \times 10^{4} \mathrm{CFU} / \mathrm{ml}$ mixed bacterial suspensions using a 2-ml syringe without the needle. Serial dilutions of the inocula were plated in LB with and without $15 \mu \mathrm{g} / \mathrm{ml}$ kanamycin for the selection of mutant and wild-type strains, respectively. Four days post-inoculation, bacteria were recovered from the infected leaves by grinding the tissue with $1 \mathrm{ml}$ of $10 \mathrm{mM} \mathrm{MgCl}$, and the CFU per $\mathrm{cm}^{2}$ were counted by plating serial dilutions on LB plates amended with the corresponding antibiotics. A competitive index $(\mathrm{CI})$ was calculated by dividing the output ratio (CFU mutant:CFU wild-type) by the input ratio (CFU mutant:CFU wild-type). The competition indices shown are the means of three replicates showing typical results from two independent experiments, i.e. six replicates in total. Statistical analysis of CI values was carried out using Student's $t$ test and the hypothesis that the mean index was not significantly different from 1.0 $(P$-value $=0.005)$.

\section{Fluorescence imaging}

Fluorescence images of the adaxial (AD) surfaces of leaves were captured with the customized fluorescence imaging system Open FluorCam FC 800-O (Photon Systems Instruments, Brno, Czech Republic). Autofluorescence emission of the leaves was excited with a UV source $(360 \mathrm{~nm})$, and the F440, F520 and F690 images were acquired sequentially from identical fields of view according to [38]. Black and white images of both measured fluorescence intensity and the calculated fluorescence ratio (F440F690) are shown using a false color scale. Images and numerical data from regions of interest were processed with FluorCam software version 7.1.0.3 (PSI Systems, Brno, Czech Republic). Measurements were carried out in mock-control and bacterialchallenged plants at 2, 4, 7, and 9 dpi. Four plants per treatment were analyzed, and the experiment was carried out three times with similar results.

\section{Results and discussion}

Genomic context analysis of the iaaL and matE loci in $P$. syringae and $P$. savastanoi

Gene iaaL is widely distributed within the $P$. syringae complex, mainly within genomospecies 2,3 and 4 corresponding to phylogenetic Multi-Locus Sequence Typing (MLST) groups 3, 1 and 4, respectively [22, 39]. Conversely, the iaaL phylogeny is largely congruent with that of the $P$. syringae complex deduced from housekeeping genes, suggesting that $i a a L$ is ancestral to the complex. Furthermore, several copies of iaaL are often found in close proximity to insertion sequences or encoded in plasmids, all of which provide evidence of horizontal transfer [11, 40]. Genomic context analysis of the iaaL gene in a selection of sequenced $P$. syringae and $P$. savastanoi strains belonging to genomospecies 2, 3 and 4 revealed that this gene is under synteny with the matE gene in all of these strains (Fig. 1a). Bioinformatics prediction of transmembrane helices in the Pto DC3000 MatE protein using the TMHMM Server v.2.0 showed a distribution of 12 putative transmembrane helical regions (Additional file 1: Figure S1) characteristic of the MATE family transporters [28, 41]. Furthermore, several ORFs were conserved in presence and arrangement in all strains belonging to genomospecies 3, e.g., P. syringae pv. lachrymans MAFF302278 and Pto DC3000. These ORFs encode for an outer membrane porin (oprD), an $\mathrm{Na}^{+} / \mathrm{H}^{+}$ antiporter (nhaP) and two hypothetical proteins. In contrast, strains belonging to genomospecies 2 demonstrated a completely different genomic context, both among each other and in comparison with genomospecies 3. In agreement with the suggested horizontal transfer of the iaaL gene among strains of the $P$. syringae complex [11], insertion sequence elements were found upstream of the mat $E$ gene in the genomes of all genomospecies 2 strains analyzed (Fig. 1a). A role for these insertion sequences in the dissemination and evolution of IAA-related genes was previously suggested by other authors [42, 43]. Moreover, synteny was not maintained in the downstream region of the matE-iaaL loci for any of the genomes analyzed (Fig. 1a), further supporting the possible integration of a mobile matE-iaaL cassette at different genome locations during the evolution of this bacterial group.

The existence of hrp box promoter sequences upstream of both the iaaL and matE genes has been reported in Pto DC3000 [17-20]. However, these two hrp box motifs were defined as non-canonical $[17,18,20]$. Although polymorphisms in hrp box sequences have been correlated with the loss of HrpL-dependent expression [18], the divergent hrp box promoter of the iaaL gene [19] actually binds HrpL and promotes HrpL-dependent transcription [20]. Interestingly, the promoter sequence of the iaaL gene is encoded within the 3' end of the matE gene in Pto DC3000 (Fig. 1b), suggesting that it could be constrained by the genetic code. Indeed, multi-sequence alignment of the iaaL promoter showed a conserved 5'-GGAACC- $\mathrm{N}_{20}$-TCAT-3' motif in the genomes of all $P$. syringae strains analyzed, including members of genomospecies 2, 3 and 4 (Fig. 1b). Other hrp box promoters found embedded within their upstream encoded ORFs include PSPTO_2130 and its orthologs, which are also members of the non-effector genes included in the P. syringae HrpL regulon [18].

In terms of the promoter region of matE, a highly conserved hrp box motif, 5'-GGAACT-N 19 -TCAG-3', was found in the strains of genomospecies 3 and exhibited a slight variation in its -35 box (5'-GGAGCT-3') in $P$. syringae pv. oryzae (Por) 1_6 (genomospecies 4, MLST 


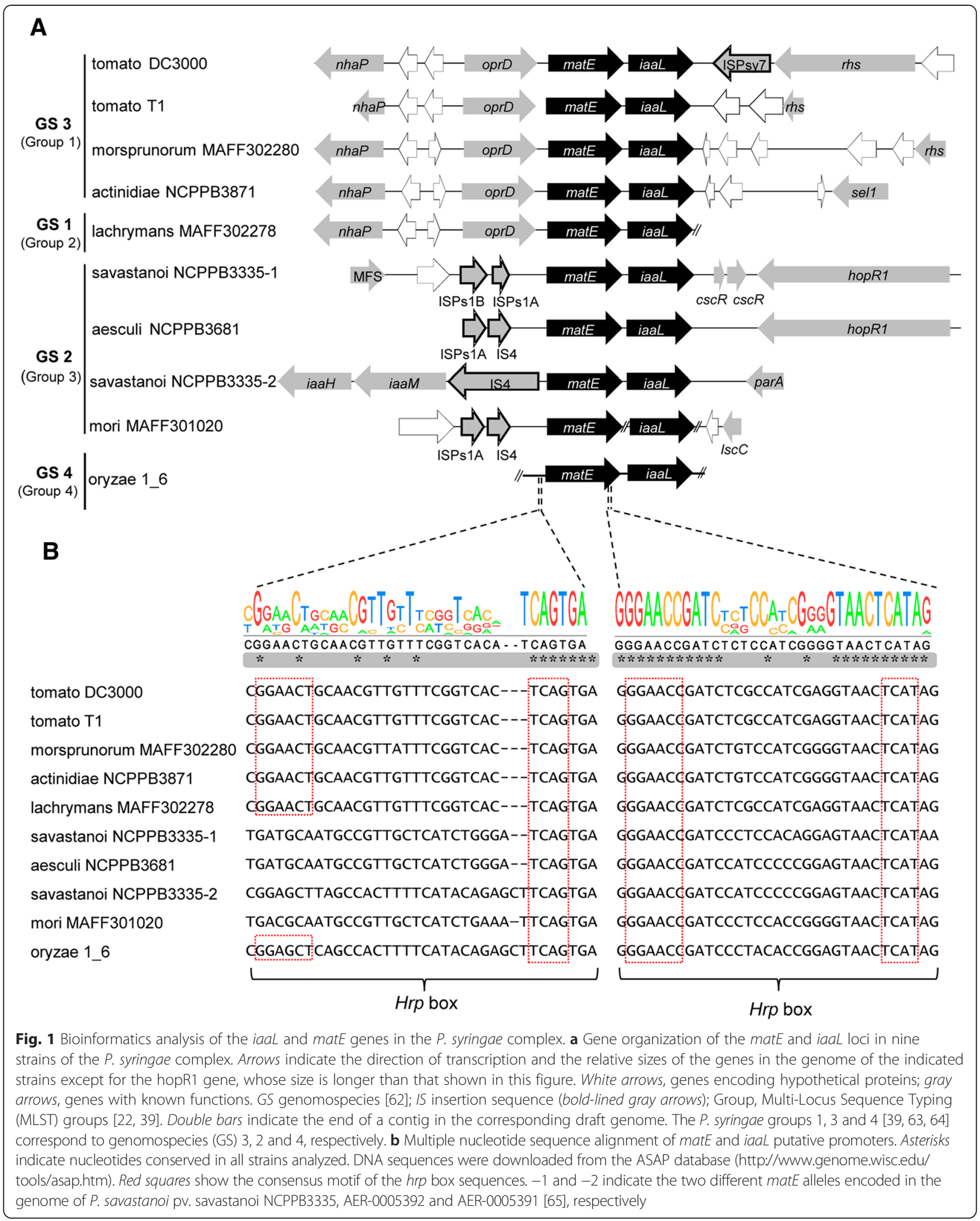


group 4). However, although the putative -10 region of this promoter $\left(5^{\prime}\right.$-TCAG-3') was also conserved in all strains included in genomospecies 2, a consensus -35 region was not found in the genomes analyzed (Fig. 1b), suggesting a possible loss of HrpL regulation of the matE promoter in this genomospecies. Transcription of the matE gene has been shown to be upregulated in response to HrpL overexpression both in Pto DC3000 (genomospecies 3) and Por 1_6 (genomospecies 4) [18], suggesting that the polymorphisms observed between these genomospecies in the $-35 \mathrm{hrp}$ box of matE do not seem to alter HrpL-dependent transcription of this gene. Low conservation of the -35 region has been observed for other promoters regulated by extracytoplasmic function (ECF) sigma factors, of which HrpL is an example [44, 45], and also for RpoD-dependent promoters [46, 47], However, downregulation of matE in a $\triangle h r p L$ background has not yet been reported for any $P$. syringae strain.

\section{The iaa gene is transcribed both independently and in formation in an operon with the matE gene}

RNA-Seq combined with Illumina high-throughput sequencing technology have been used to identify 5 '-ends of transcripts in Pto DC3000 grown in iron-limited MG medium, including those corresponding to the iaaL gene $[33,34]$. Moreover, transcriptome profiling using RNAseq coupled with the GENE-counter software package [48] recently expanded characterization of the HrpL regulon from six P. syringae strains, including Pto DC3000, and pointed again at the iaaL and matE genes as members of this regulon [18]. Moreover, chromatin immunoprecipitation coupled with high-throughput sequencing (ChIP-Seq) and RNA-Seq was used to identify HrpLbinding sites and likely hrp promoters, including that of the iaaL gene [20]. Despite the growing use of RNA-Seq as a high-throughput strategy to analyze the transcriptome of Pto DC3000 on a global scale, very few confirmed transcriptional start sites have been reported for this model pathogen [34]. With the experimental aim of confirming the transcription start sites of both the iaaL and matE genes in Pto DC3000, we first used primer extension analysis and then 5'RACE. The transcription start site of iaaL was located just three nucleotides downstream of the $3^{\prime}$ end of its proximal hrp box promoter, at the $\mathrm{C}$ located $79 \mathrm{bp}$ upstream of its start codon (Additional file 2: Figure S2). This position is placed two nucleotides upstream and one nucleotide downstream, respectively, of those previously determined [20,34]. Extension of several primers complementary to the matE sequence yielded no amplification products. However, the transcription initiation site of the matE gene was identified by $5^{\prime} \mathrm{RACE}$ at the $\mathrm{G}$ located 66 bp upstream of its start codon (Additional file 2: Figure S2). This start site is identical to one of the two possible sites proposed by [34] and is located 17 bp downstream of the $3^{\prime}$ end of its proximal hrp box promoter (Fig. 1). A detailed analysis of the transcription start sites of HrpL-regulated promoters determined in Pto DC3000 by [34] revealed that most of them, 39 of the 49 identified, were located at a distance within 2-4 bp to the proximal hrp box promoter; the remaining distances from the start sites ranged from 0 to $75 \mathrm{bp}$ (Additional file 3: Figure S3).

The existence of a matE-iaaL operon has been suggested in both Pto DC3000 [18-20] and Pto T1 [49]. However, co-transcription of these two genes has not been experimentally demonstrated to date. To further explore this hypothesis, RT-PCR analyses were performed using total RNA extracted from Pto DC3000 together with forward and reverse primers (Additional file 4: Table S1) annealing within the iaaL and matE gene sequences, respectively (Fig. 2a). A product of approximately $2.1 \mathrm{~Kb}$, including most of the matE ORF, the intergenic region between matE and $i a a L$ and more than $70 \%$ the iaaL ORF, was obtained and confirmed by sequencing. A putative rho-independent transcriptional terminator was located using a web interface [50] near the $3^{\prime}$ end of this amplicon (Fig. 2b). However, a product of approximately $1.8 \mathrm{~Kb}$ spanning from the 3 ' end of the matE gene to $196 \mathrm{bp}$ downstream of the stop codon of iaaL was also obtained (Fig. 2b), further supporting the notion of the co-transcription of matE and iaaL. Together, all of these results demonstrate that the Pto DC3000 iaaL gene can be transcribed both independently and as an operon with the matE gene.

\section{Transcription from the $P$. syringae pv. tomato DC3000 $\mathbf{P}_{\text {mate }}$ promoter is HrpL-dependent}

To unveil the HrpL-dependency of the expression of the matE gene, a $\triangle h r p L$ Pto DC3000 mutant was constructed. To analyze the in vivo activity of the predicted promoter region of matE $\left(\mathrm{P}_{\text {mat }}\right)$, a transcriptional fusion of this promoter to lacZ was constructed and transformed into both the wild-type strain Pto DC3000 and its $\Delta h r p L$ mutant. In addition, Pto strains expressing a fusion of the iaaL promoter $\left(\mathrm{P}_{\text {iaaL }}\right)$ to lac $Z$ were also constructed for comparison. A Pto DC3000 transformant carrying the plasmid pMP220 (empty vector) was used as a negative control. In the wild-type strain, the activity of $\mathrm{P}_{\text {mat }}$ increased along the growth curve, reaching a maximal expression of over 500 Miller units after $72 \mathrm{~h}$ (late stationary phase). Moreover, this activity was clearly higher than that found for the $\Delta h r p L$ mutant, whose activity remained substantially consistent throughout the growth curve, and higher than that observed for Pto DC3000 carrying the empty vector (Fig. 3a). Thus, our results show that the expression from $\mathrm{P}_{\text {mat }}$ in Pto DC3000 may take place from two different promoters: one weak and constitutive and another stronger 


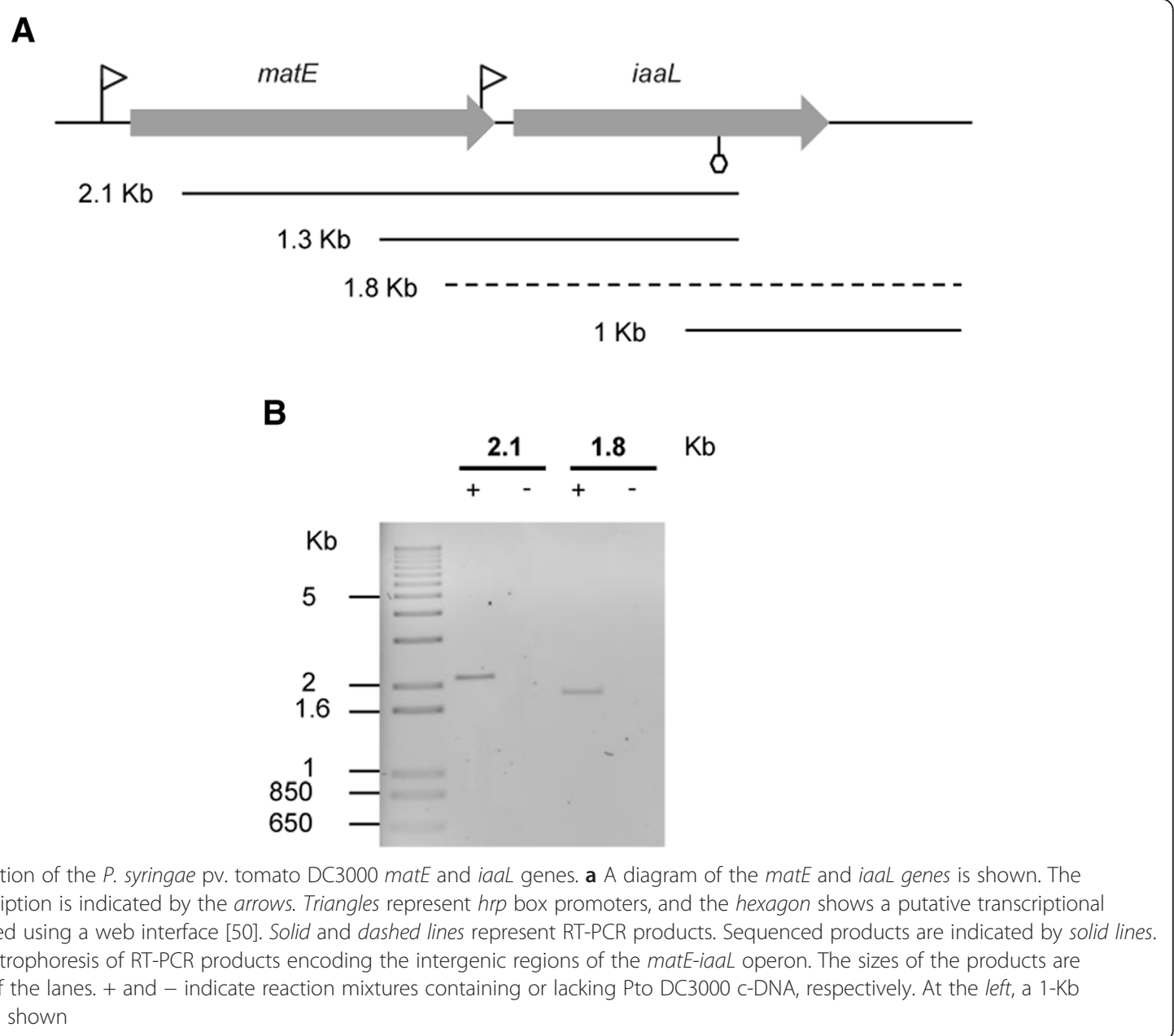

and HrpL-dependent. With the exception of P. syringae pv. morsprunorum (Pmp) MAFF302280, all other P. syringae strains belonging to genomospecies 1 and 3 analyzed in this study encode a $\mathrm{P}_{\text {mate }}$ promoter sequence identical to that of Pto DC3000 (Fig. 1b). Thus, it could be expected that the expression of matE in all these strains is also activated by HrpL. Polymorphisms in the consensus hrp box promoter sequence have been shown to be responsible for the loss of HrpL-dependent transcription of other noneeffector genes in Pto DC3000, i.e., the promoter sequences of PSPTO_2130 and PSPTO_2105 [18]. Therefore, the polymorphisms observed in the promoter sequences of $\mathrm{P}_{\text {mat }}$ in Pmp MAFF302280 and in the strains of $P$. syringae and $P$. savastanoi included in genomospecies 1,2 and 4 (Fig. 1b) might be responsible for the recruitment of the matE gene to the HrpL regulon in all of these strains. However, this hypothesis has yet to be tested.

The activity of the $\mathrm{P}_{\text {iaal }}$ promoter increased after $6 \mathrm{~h}$ and remained moderately stable from 24 to $56 \mathrm{~h}$, reaching a maximum level of approximately 200 Miller units after $72 \mathrm{~h}$. In agreement with other authors [20], the activity of this promoter was fully dependent on HrpL, as ß- galactosidase activity levels obtained in the $\Delta h r p L$ mutant were generally similar to those of the negative control (Fig. 3b). In summary, expression from both $\mathrm{P}_{\text {matE }}$ and $\mathrm{P}_{\text {iaaL }}$ is dependent on HrpL and is induced in late stationary phase, although the induction levels of $\mathrm{P}_{\text {mate }}$ are approximately 2.5 times higher than $\mathrm{P}_{i a a L}$ under the conditions tested. Although analysis of $P$. syringae virulence has primarily focused on the characterization and function of the T3SS and its effector proteins, a role in virulence has also been demonstrated for other noneffector genes regulated by HrpL, e.g., the Pto DC300 $\operatorname{corR}[17,51]$ and aprI $[20,52]$ genes and the PSPPH_A0106-A0112 operon of $P$. syringae pv. phaseolicola 1448A [18]. In the light of these findings, the possible roles of the matE and iaaL genes in the survival and virulence of Pto DC3000 in tomato plants were analyzed.

The iaa $L$ and matE genes are required for full virulence of $P$. syringae pv. tomato $\mathrm{DC} 3000$ in tomato plants

To analyze the roles of the iaaL and matE genes in the fitness and virulence of Pto DC3000, knock-out mutants 


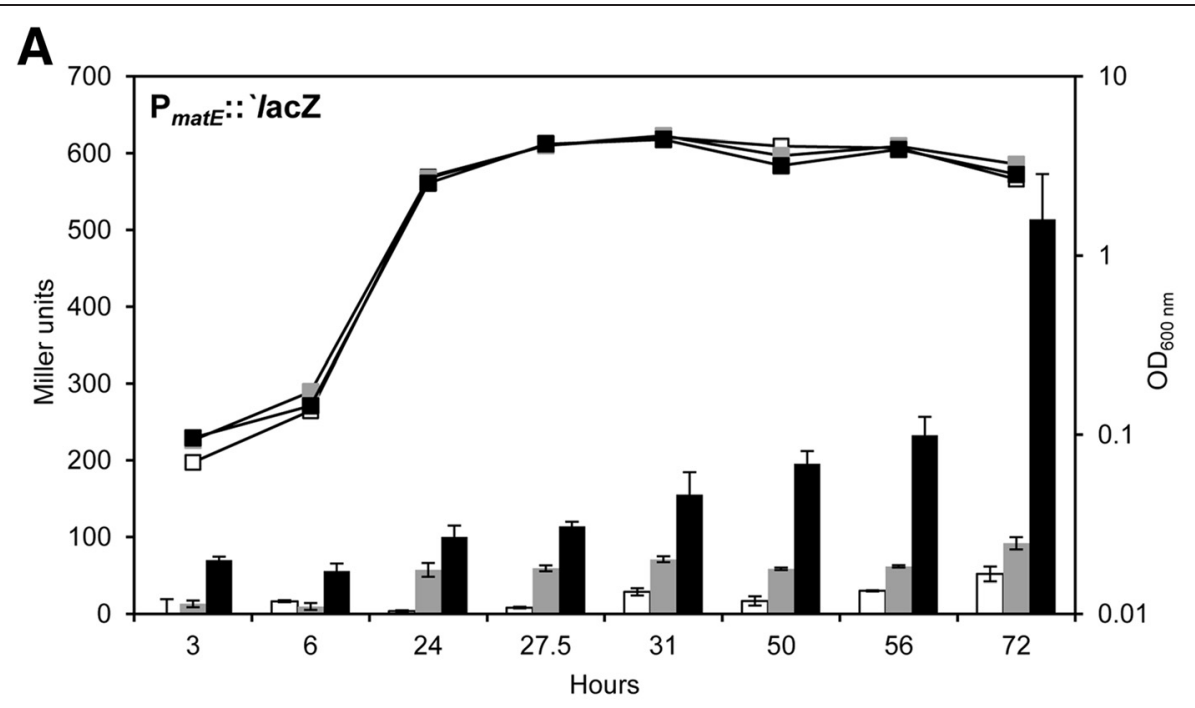

B

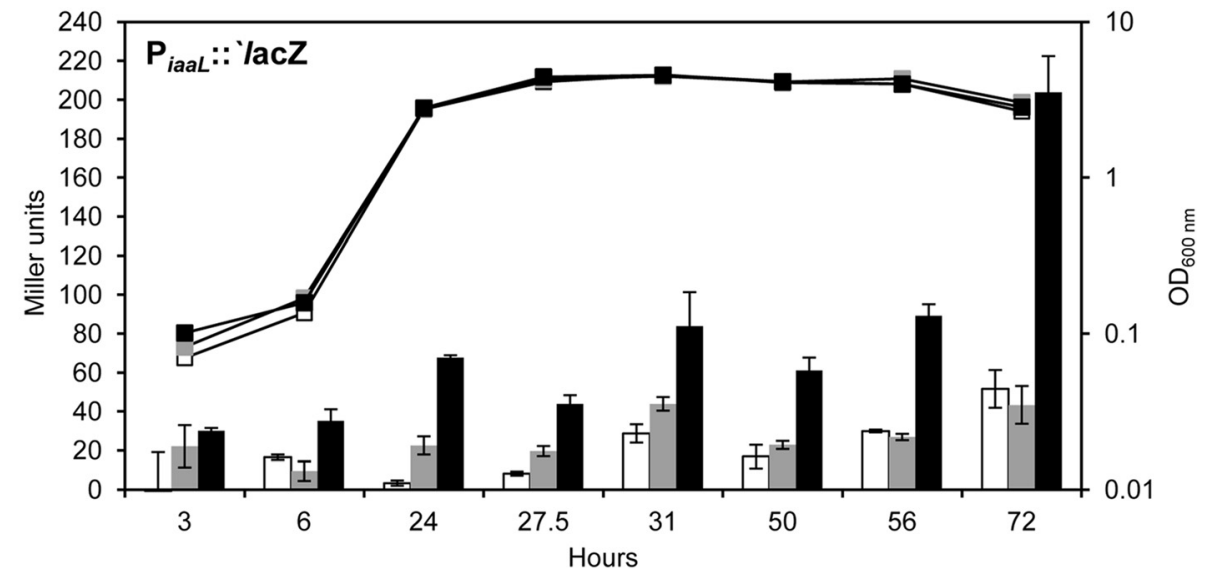

Fig. 3 HrpL-dependent expression of the matE $\left(P_{\text {mate }}\right)$ and iaaL $\left(P_{\text {iaal }}\right)$ promoters in P. syringae pv. tomato (Pto) DC3000. Growth curves of wild-type Pto DC3000 transformed with the empty vector pMP220 (white) or with a vector carrying the promoter fusions $P_{\text {mate: : }}$ lacZ (a) or $P_{\text {iaal }}:$ "lacZ (b) (black). Bars show the $\beta$-galactosidase activity obtained from $P_{\text {matE: }} / a c Z$ (a) or Piaal:: lacZ (b) during the growth of Pto DC3000 derivatives on minimal M9

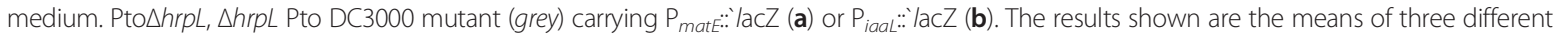
experiments with their respective standard deviations

of each of these genes and their corresponding complemented strains were constructed. While the $\Delta i a a L$ mutant carried a deletion of the complete iaaL ORF, the $\triangle m a t E$ mutant encoded a deletion expanding from the start codon of the gene to 61 bp upstream of its $3^{\prime}$ end. Thus, the $\Delta$ matE deletion did not affect the hrp box of $\mathrm{P}_{\text {iaaL }}$, which is embedded in the $3^{\prime}$ end of matE (Fig. 1). Competition assays between each of the mutants, or their corresponding complemented strains, against the wild-type strain Pto DC3000 were carried out. Tomato leaves were infiltrated with mixed inocula (1:1), and after 5 days, bacteria were recovered and viable cells were counted. The results shown in Fig. 4a are expressed as competition indices $(\mathrm{CI})$ of the mutants ( $\triangle i a a L$ and $\Delta m a t E)$ or complemented strains ( $\triangle i a a L \mathrm{pJB} 3-i a a L$ and
$\Delta m a t E$ pJB3-matE) relative to the wild-type strain. The ability of both mutant strains to multiply and survive in planta was clearly impaired in comparison with the wild-type strain, as reflected by the CI values of approximately 0.5 obtained for each of the mutants. However, ectopic expression of the iaaL or matE genes in their corresponding mutant strains yielded $\mathrm{CI}$ values that were not significantly different from one (Fig. 4a), demonstrating full complementation of the growth defects of the mutants via plasmid-borne expression of the deleted genes. Under the same conditions used in this study, CI assays have previously permitted the detection of virulence phenotypes for Pto DC3000 genes, including T3SS effectors proven to be functionally redundant [53]. Thus, our results demonstrate that the matE and iaaL genes are both required for 

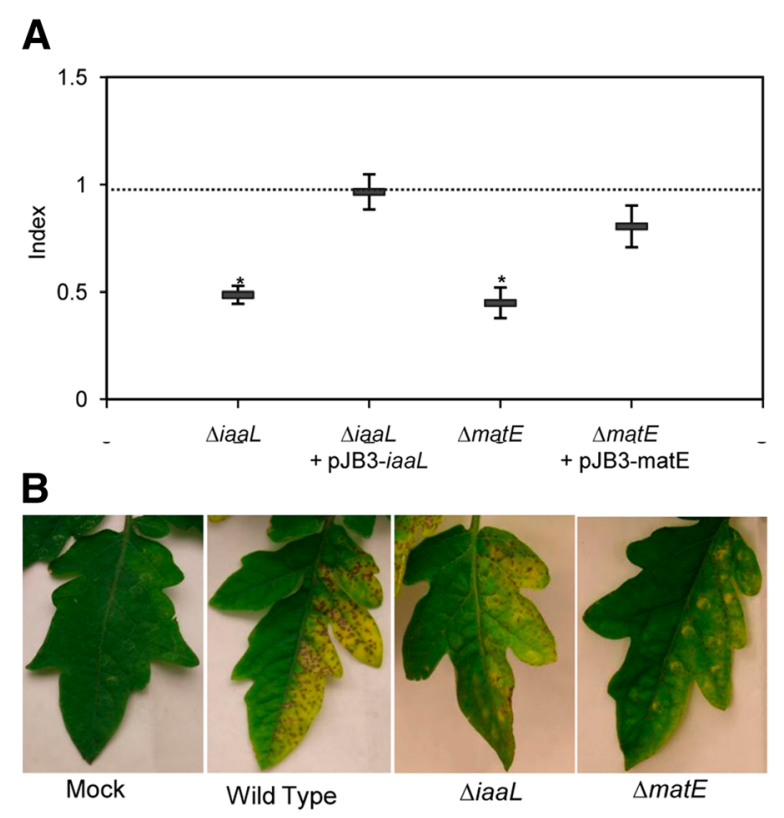

C

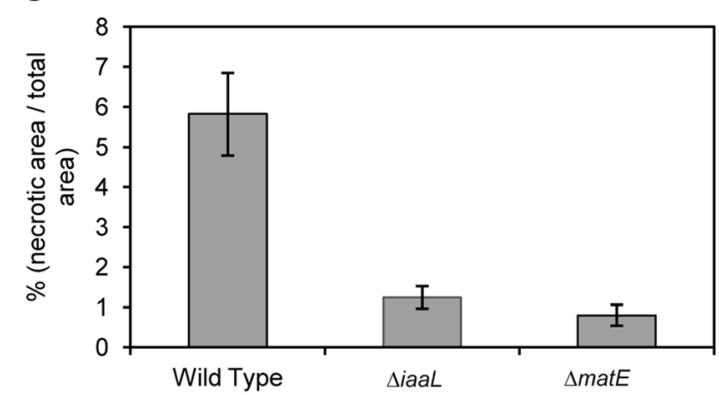

Fig. 4 Hypovirulence of $P$. syringae pv. tomato DC3000 iaaL and matE mutants in tomato plants. a Competitive index $(\mathrm{Cl})$ values for mixed inoculations of P. syringae pv. tomato DC3000 and its derivate strains in tomato plants. Complementation was performed via ectopic expression of iaaL or matE cloned in the expression vector pJB3 (Table 1). Error bars indicate the standard error from the average of two different assays. Asterisks indicate $\mathrm{Cl}$ values that were significantly different from one. Statistical analyses were performed using Student's $t$-test and $P=0.005$. b Representative images of symptoms induced by the indicated strains in var. Moneymaker tomato plants at 9 days post-inoculation (dpi). Mock, plants inoculated with a $\mathrm{MgCl}_{2}$ solution. c Quantification of necrotic areas in the leaflets shown in (b). The results are the means of nine different leaflets. Error bars represent the standard error

growth and survival of Pto DC3000 in tomato leaves. Virulence of bacterial pathogens in host plants, including Pto DC3000 [15], is often dependent on their ability to grow and survive in plant tissues. Therefore, we decided to test the ability of the Pto DC3000 $\Delta i a a L$ and $\Delta m a t E$ mutants to cause disease in tomato leaves.

Figure $4 \mathrm{~b}$ shows the symptoms in tomato leaves caused by wild-type Pto DC3000 and the $\Delta i a a L$ and $\triangle$ mat $E$ mutants at 9 dpi. Moreover, image analysis of infected leaves was also performed at $9 \mathrm{dpi}$, allowing the quantification of the symptoms induced as the ratio of necrotic lesions/total leaf area (Fig. 4c). At 9 dpi, chlorosis of the tissue induced by wild-type Pto DC3000 covered the entire inoculated area, and the necrotic lesions covered approximately $6 \%$ of the total leaf area. In contrast, leaves inoculated with the $\Delta m a t E$ or $\Delta i a a L$ mutants developed late chlorosis and exhibited significantly fewer necrotic lesions than those caused by the wild-type strain (approximately 0.8 and $1.2 \%$ of the total leaf area, respectively) (Fig. $4 \mathrm{~b}$ and c). Therefore, both $m a t E$ and iaaL are needed for growth and fitness of Pto DC3000 in tomato leaves, which also have an effect on its virulence.

It has been recently studied whether some of the noneffector genes identified as new members of the Pto DC3000 HrpL regulon contributed to pathogenicity. For that, deletion mutants were constructed (on wild-type Pto DC3000 and 4 hopQ1-1 backgrounds) for seven candidates, including the iaaL gene. Despite the fact that the annotated functions of all seven genes were elusive in terms of plant association, no phenotypic differences were observed for in planta growth, virulence, or HR for any of these mutants in Nicotiana benthamiana plants [20]. In addition to differences in the experimental design of these two pathogenicity tests, the iaaL gene may have a relevant role in the interaction of this pathogen with tomato plants and not with $N$. benthamiana, a host plant for a mutant lacking the T3SS effector HopQ1-1 but not for wild-type Pto DC3000 [54]. On the other hand, MatE most likely contributes to the intrinsic bacterial resistance to toxic compound(s) produced by tomato plants, thus promoting Pto DC3000 survival during infection. Since the matE gene was shown to be induced in planta [21], the contribution of MatE to bacterial resistance might be emphasized in this case.

\section{Multicolor fluorescence imaging of infected tomato plants}

Imaging techniques have emerged as valuable tools to investigate the spatial and temporal heterogeneity of plant responses to pathogens [55]. Multicolor fluorescence imaging (MCFI) can reveal leaf patterns of autofluorescence emitted either by chlorophyll or secondary metabolites involved in plant defense (BFG, blue-green fluorescence), allowing pathogen diagnosis in the absence of visual symptoms [56-58] Excitation of leaves with long-wavelength UV radiation results in the emission of characteristic broad fluorescence bands at approximately $440 \mathrm{~nm}$ (blue; F440), $520 \mathrm{~nm}$ (green; F520), and $690 \mathrm{~nm}$ (red; F690). The first two fluorescence bands are emitted by phenolic compounds, most of which accumulate in response to stress, and the latter by chlorophyll [55]. Here, we used MCFI to describe the responses of tomato plants to wild-type Pto DC3000 and 
its $\triangle$ matE and $\triangle i a a L$ mutants. At $2 \mathrm{dpi}$, a severe increase in F440 (Fig. 5a and b) and F520 (Fig. 5c and d) was observed in the tissues infiltrated with the wild-type strain compared to the corresponding zones of the mock-control leaves. These results suggested the activation of secondary metabolism related to phenolic compounds in response to bacterial infection. Both F440 (Fig. 5a and b) and F520 (Fig. 5c and d) reached very high values in the final stages of infection (7 dpi and, particularly, at $9 \mathrm{dpi}$ ), due to tissue necrosis [59]. Leaves infiltrated with either the $\Delta m a t E$ or the $\triangle i a a L$ mutant exhibited the same trend at 2 and $4 \mathrm{dpi}$; however, F440 and F520 reached lower values than in the case of leaves infected with the wild-type strain (Fig. 5). Our results are in agreement with previous studies reporting an increase in BGF in plants infected by pathogens $[38,56,57,60]$. Moreover, these results correlate with the reported accumulation of flavonoids and other phenolic compounds in tomato plants infected with Pto DC3000 [61]. Interestingly, and concomitant with the hypovirulent phenotypes demonstrated by the $\Delta m a t E$ and $\Delta i a a L$ mutants (Fig. 4), the observed changes in F440, F520 were strongest in the case of plants challenged by the wild-type strain, indicating lower activation of secondary metabolism in plants infected with the $\Delta$ matE and $\Delta i a a L$ mutants (Fig. 5). All of these plant responses were expected for the decreased bacterial populations exhibited by the mutant strains in comparison with the wild-type strain (Fig. 4).

\section{Conclusions}

After the complete genome sequencing of Pto DC3000, the application of several high-throughput experimental screens and bioinformatics approaches allowed the identification of a suite of genes regulated by the sigma factor HrpL in this model bacterial phytopathogen. In addition to the genes required for the biosynthesis of T3SS and its effectors, other non-effector regulon members with diverse functions were also identified, including the $i a a L$ gene and the putative MATE family transporter gene here called matE. In this work, we show that the iaaL gene, which is highly conserved within the $P$. syringae complex, is found in synteny with the matE gene in the genome of $P$. syringae and $P$. savastanoi strains belonging to genomospecies 2,3 and 4 . We demonstrate that

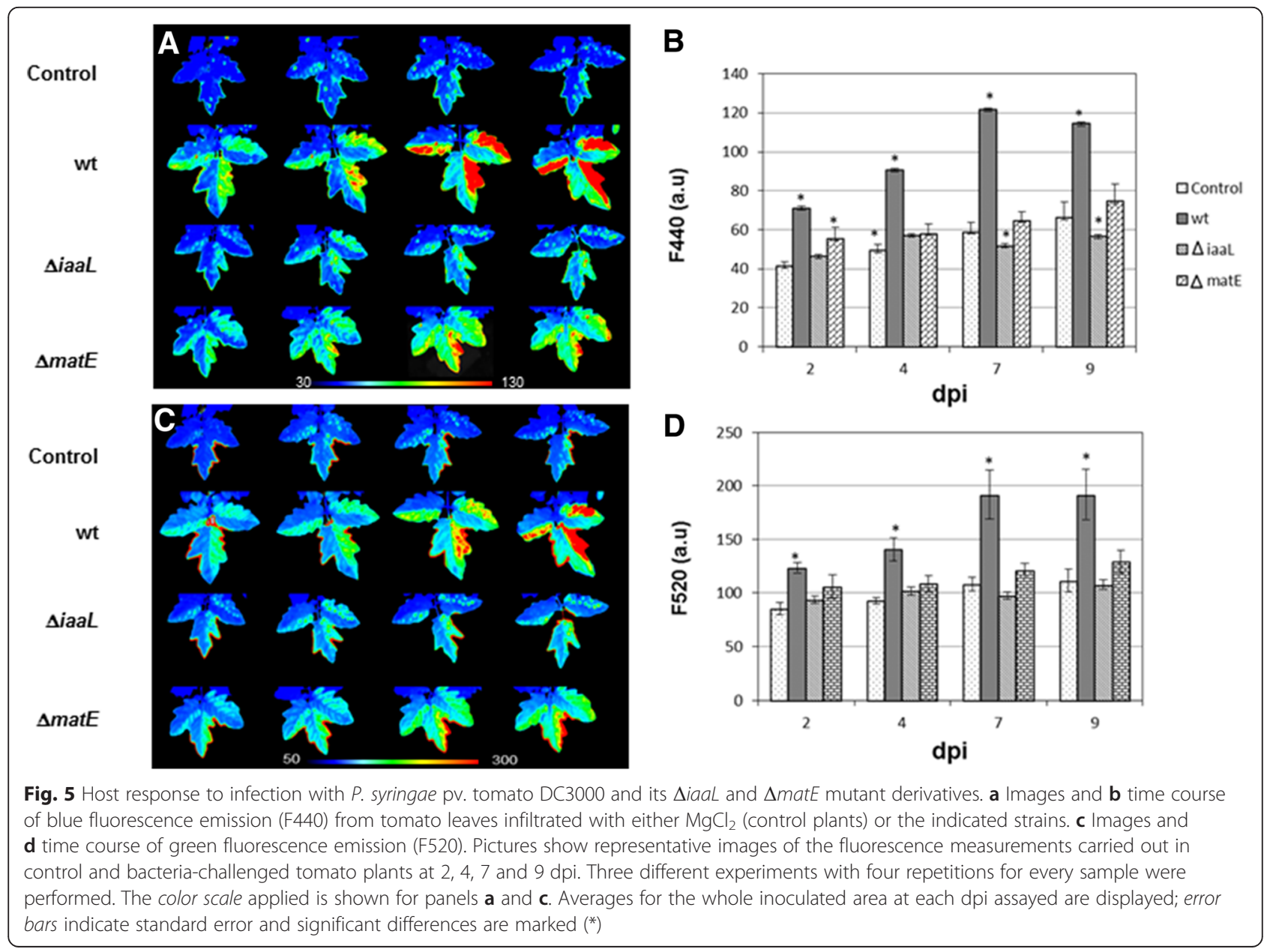


in Pto DC3000, both of these genes encode upstream hrp box-like promoters that are HrpL-dependent. We also present evidence for the cotranscription of iaaL and matE (matE-iaaL operon) in this pathogen. Finally, we show that deletion of either the iaaL or the matE gene in Pto DC3000 results in decreased fitness, colonization and virulence, together with a lower activation of secondary metabolism in infected tomato plants.

\section{Additional files}

Additional file 1: Figure S1. Prediction of transmembrane helices in the MatE protein of $P$. syringae pv. tomato DC3000. Transmembrane regions are shown in red, internal regions in blue, and external regions in pink. The Y-axis shows the probability of the domains being transmembrane, internal or external regions. (TIFF $503 \mathrm{~kb}$ )

Additional file 2: Figure S2. Determination of the transcription start sites of the iaaL and matE genes in P. syringae pv. tomato DC3000. Total RNA of $P$. syringae pv. tomato DC3000 grown on minimal media was extracted. (A) For iaaL, runoff cDNAs were generated by extending primers R161 and R121 (Table S1). Lanes A, C, G, and T contain the products of the dideoxy sequencing reactions with using primer R161. Arrows indicate the size of the runoff CDNAs obtained for each primer. (B) Nucleotide sequence of the intergenic region including the $3^{\prime}$ and $5^{\prime}$ ends of the matE and iaaL ORFS, respectively. (C) For matE, the +1 position was determined by $5^{\prime}$ RACE and subsequent sequencing. B and $\mathrm{C}$ : The coding sequences of both genes are shadowed. The transcription start sites $\left(\mathrm{P}_{\text {iaal }}\right.$ /mate $)$ are marked with a black spot and are shown in bold type; the arrowhead indicates the direction of transcription. The hrp box motifs are shown in gray boxes, and the sequences of the primers used are underlined. (TIFF $3064 \mathrm{~kb}$ )

Additional file 3: Figure S3. Distances of the predicted transcriptional start sites of $P$. syringae pv. tomato DC3000 HrpL-regulated genes starting from the $3^{\prime}$ ends of their corresponding hrp boxes. Distances were calculated using the 52 annotated hrp-boxes (http://www.pseudomonas-syringae.org/) and the 49 transcription start sites previously predicted [34]. (TIFF $164 \mathrm{~kb}$ )

Additional file 4: Table S1. Primers used in this study. (DOC $57 \mathrm{~kb}$ )

\section{Competing interests}

The authors declare that they have no competing interests.

\section{Authors' contributions}

Conceived and designed the experiments: MGC-L, IMA, VC, IMM, MLPB, MTG, MB, CR. Performed the experiments: MGC-L, IMA, VC. IMM, MLPB. Analyzed the data: MGC-L, IMA, VC, IMM, MLPB, MTG, MB, CR. Contributed reagents/ materials/analytical tools: MTG, MB, CR. Wrote the paper: MGC-L, IMA, MLPB, MTG, MB, CR. All authors read and approved the final manuscript.

\section{Acknowledgments}

This research was supported by the Spanish Plan Nacional I+D+i grants AGL2011-30343-CO2-01, AGL2014-53242-C2-1-R and BIO2007-67874-C02-02 as well as by grants ref. P08-CVI-03475 and P12-AGR-0370 from the Junta de Andalucía (Spain). A. de Vicente and V. Carrión (University of Malaga, Spain) are thanked for help with the analysis of virulence in tomato plants and for assistance with 5'-RACE, respectively. We thank Manuela Vega [Servicio Centrales de Apoyo a la Investigación (SCAl), University of Malaga, Spain] for excellent assistance with the image analysis of knot volumes. We also thank $M$. Pineda (EEZ, CSIC, Granada, Spain) for fruitful discussions and technical help with imaging techniques.

\section{Author details}

'Área de Genética, Universidad de Málaga, Instituto de Hortofruticultura Subtropical y Mediterránea "La Mayora", Universidad de Málaga-CSIC (IHSM-UMA-CSIC), Campus de Teatinos, 29071 Málaga, Spain. ' ${ }^{2}$ German Center for Neurodegenerative Diseases, DZNE, Otfried-Müller-Straße, 27,
72076 Tübingen, Germany. ${ }^{3}$ Estación Experimental del Zaidín, CSIC (EEZ-CSIC), Profesor Albareda 1, 18008 Granada, Spain. ${ }^{4}$ Departamento de Producción Agraria, Universidad Pública de Navarra, Pamplona, Navarra, Spain.

Received: 7 May 2015 Accepted: 6 August 2015

Published online: 19 August 2015

\section{References}

1. Spaepen S, Vanderleyden J, Remans R. Indole-3-acetic acid in microbial and microorganism-plant signaling. FEMS Microbiol Rev. 2007;31(4):425-48. doi:10.1111/j.1574-6976.2007.00072.x.

2. Gielen J, De Beuckeleer M, Seurinck J, Deboeck F, De Greve H, Lemmers M, et al. The complete nucleotide sequence of the TL-DNA of the Agrobacterium tumefaciens plasmid pTiAch5. EMBO J. 1984;3(4):835-46.

3. Yamada T, Palm CJ, Brooks B, Kosuge T. Nucleotide sequences of the Pseudomonas savastanoi indoleacetic acid genes show homology with Agrobacterium tumefaciens T-DNA. Proc Natl Acad Sci U S A. 1985;82(19):6522-6.

4. Hutzinger $\mathrm{O}$, Kosuge T. Microbial synthesis and degradation of indole-3-acetic acid. 3. The isolation and characterization of indole-3-acetyl-epsilon-L-lysine. Biochemistry. 1968;7(2):601-5.

5. Hutzinger O, Kosuge T. 3-Indoleacetic-L-lysine, a new conjugate of 3indoleacetic acid produced by Pseudomonas savastanoi. In: Wightmanand F, Setterfield G, editors. Biochemistry and physiology of plant growth substances. Ottawa, Canada: The Runge Press Ltd.; 1968. p. 183-94.

6. Evidente A, Surico G, lacobellis NS, Randazzo G. a-N-acetyl-indole-3-acetyl- $\varepsilon$ L-lysine: A metabolite of indole-3-acetic acid from Pseudomonas syringae pv. savastanoi. Phytochemistry. 1985;25(1):125-8. doi:10.1016/s0031-9422(00)94515-1.

7. Glass NL, Kosuge T. Cloning of the gene for indoleacetic acid-lysine synthetase from Pseudomonas syringae subsp. savastanoi. J Bacteriol. 1986;166(2):598-603.

8. Glass NL, Kosuge T. Role of indoleacetic acid-lysine synthetase in regulation of indoleacetic acid pool size and virulence of Pseudomonas syringae subsp. savastanoi. J Bacteriol. 1988;170(5):2367-73.

9. Roberto FF, Klee H, White F, Nordeen R, Kosuge T. Expression and fine structure of the gene encoding $\mathrm{N}$ epsilon-(indole-3-acetyl)-L-lysine synthetase from Pseudomonas savastanoi. Proc Natl Acad Sci U S A. 1990;87(15):5797-801.

10. Glickmann E, Gardan L, Jacquet $\mathrm{S}$, Hussain $\mathrm{S}$, Elasri M, Petit A, et al. Auxin production is a common feature of most pathovars of Pseudomonas syringae. Mol Plant Microbe Interact. 1998;11(2):156-62. doi:10.1094/ MPMI.1998.11.2.156.

11. Ramos C, Matas IM, Bardaji L, Aragón IM, Murillo J. Pseudomonas savastanoi pv. savastanoi: some like it knot. Mol Plant Pathol. 2012;13(9):998-1009. doi:10.1111/j.1364-3703.2012.00816.x.

12. Aragón IM, Pérez-Martínez I, Moreno-Pérez A, Cerezo M, Ramos C. New insights into the role of indole-3-acetic acid in the virulence of Pseudomonas savastanoi pv. savastanoi. FEMS Microbiol Lett. 2014;356(2):184-92. doi:10.1111/1574-6968.12413.

13. Pérez-Martínez I, Zhao Y, Murillo J, Sundin GW, Ramos C. Global genomic analysis of Pseudomonas savastanoi pv. savastanoi plasmids. J Bacteriol. 2008;190(2):625-35. doi:10.1128/jb.01067-07.

14. Buell CR, Joardar V, Lindeberg M, Selengut J, Paulsen IT, Gwinn ML, et al. The complete genome sequence of the Arabidopsis and tomato pathogen Pseudomonas syringae pv. tomato DC3000. Proc Natl Acad Sci U S A. 2003;100(18):10181-6. doi:10.1073/pnas.1731982100.

15. Cunnac $S$, Chakravarthy $S$, Kvitko BH, Russell AB, Martin GB, Collmer A. Genetic disassembly and combinatorial reassembly identify a minimal functional repertoire of type III effectors in Pseudomonas syringae. Proc Natl Acad Sci U S A. 2011;108(7):2975-80. doi:10.1073/pnas.1013031108.

16. Preston GM. Pseudomonas syringae pv. tomato: the right pathogen, of the right plant, at the right time. Mol Plant Pathol. 2000;1(5):263-75. doi:10.1046/j.1364-3703.2000.00036.x.

17. Fouts DE, Abramovitch RB, Alfano JR, Baldo AM, Buell CR, Cartinhour $S$, et al. Genomewide identification of Pseudomonas syringae pv. tomato DC3000 promoters controlled by the HrpL alternative sigma factor. Proc Natl Acad Sci U S A. 2002;99(4):2275-80. doi:10.1073/pnas.032514099.

18. Mucyn TS, Yourstone S, Lind AL, Biswas S, Nishimura MT, Baltrus DA, et al. Variable suites of non-effector genes are co-regulated in the type III secretion virulence regulon across the Pseudomonas syringae phylogeny. PLoS Pathog. 2014;10(1), e1003807. doi:10.1371/journal.ppat.1003807. 
19. Ferreira AO, Myers CR, Gordon JS, Martin GB, Vencato M, Collmer A, et al. Whole-genome expression profiling defines the HrpL regulon of Pseudomonas syringae pv. tomato DC3000, allows de novo reconstruction of the Hrp cis element, and identifies novel coregulated genes. Mol Plant-Microbe Interact. 2006;19(11):1167-79. doi:10.1094/mpmi-19-1167.

20. Lam HN, Chakravarthy S, Wei HL, BuiNguyen H, Stodghill PV, Collmer A, et al. Global analysis of the HrpL regulon in the plant pathogen Pseudomonas syringae pv. tomato DC3000 reveals new regulon members with diverse functions. PLoS One. 2014;9(8), e106115. doi:10.1371/ journal.pone.0106115.

21. Boch J, Joardar V, Gao L, Robertson TL, Lim M, Kunkel BN. Identification of Pseudomonas syringae pv. tomato genes induced during infection of Arabidopsis thaliana. Mol Microbiol. 2002;44(1):73-88

22. Baltrus DA, Nishimura MT, Romanchuk A, Chang JH, Mukhtar MS, Cherkis K, et al. Dynamic evolution of pathogenicity revealed by sequencing and comparative genomics of 19 Pseudomonas syringae isolates. PLoS Pathog. 2011;7(7), e1002132. doi:10.1371/journal.ppat.1002132.

23. Xiao $Y$, Hutcheson SW. A single promoter sequence recognized by a newly identified alternate sigma factor directs expression of pathogenicity and host range determinants in Pseudomonas syringae. J Bacteriol. 1994;176(10):3089-91.

24. Dixon RA. Natural products and plant disease resistance. Nature. 2001:411(6839):843-7. doi:10.1038/35081178.

25. Osbourn AE. Preformed antimicrobial compounds and plant defense against fungal attack. Plant Cell. 1996;8(10):1821-31. doi:10.1105/tpc.8.10.1821.

26. Stoitsova SO, Braun Y, Ullrich MS, Weingart H. Characterization of the RND-type multidrug efflux pump MexAB-OprM of the plant pathogen Pseudomonas syringae. Appl Environ Microbiol. 2008;74(11):3387-93. doi:10.1128/AEM.02866-07.

27. Vargas P, Felipe A, Michan C, Gallegos MT. Induction of Pseudomonas syringae pv. tomato DC3000 MexAB-OprM multidrug efflux pump by flavonoids is mediated by the repressor PmeR. Mol Plant Microbe Interact. 2011;24(10):1207-19. doi:10.1094/MPMI-03-11-0077.

28. Kuroda T, Tsuchiya T. Multidrug efflux transporters in the MATE family. Biochim Biophys Acta. 2009;1794(5):763-8. doi:10.1016/j.bbapap.2008.11.012.

29. Miller JH. Experiments in molecular genetics. Cold Spring Harbor, NY: Cold Spring Harbor Laboratory; 1972.

30. Sambrook J, Russell D. Molecular cloning: a laboratory manual. 3rd ed. Cold Spring Harbor New York, USA: Cold Spring Harbor Laboratory Press; 2001.

31. Roine E, Wei W, Yuan J, Nurmiaho-Lassila EL, Kalkkinen N, Romantschuk M, et al. Hrp pilus: an hrp-dependent bacterial surface appendage produced by Pseudomonas syringae pv. tomato DC3000. Proc Natl Acad Sci U S A. 1997;94(7):3459-64.

32. Maruyama IN, Rakow TL, Maruyama HI. CRACE: a simple method for identification of the 5' end of mRNAs. Nucleic Acids Res. 1995;23(18):3796-7.

33. Filiatrault MJ, Stodghill PV, Bronstein PA, Moll S, Lindeberg M, Grills G, et al. Transcriptome analysis of Pseudomonas syringae identifies new genes, noncoding RNAs, and antisense activity. J Bacteriol. 2010;192(9):2359-72. doi:10.1128/JB.01445-09.

34. Filiatrault MJ, Stodghill PV, Myers CR, Bronstein PA, Butcher BG, Lam H, et al. Genome-wide identification of transcriptional start sites in the plant pathogen Pseudomonas syringae pv. tomato str. DC3000. PLoS One. 2011;6(12), e29335. doi:10.1371/journal.pone.0029335.

35. Spaink HP, Okker RJH, Wijffelman CA, Pees E, Lugtenberg BJJ. Promoters in the nodulation region of the Rhizobium leguminosarum Sym plasmid pRL1Jl. Plant Mol Biol. 1987:9(1):27-39. doi:10.1007/bf00017984.

36. Maloy SR. Experimental techniques in bacterial genetics. Boston, USA: Jones and Bartlett Publishers; 1989

37. Zumaquero A, Macho AP, Rufian JS, Beuzon CR. Analysis of the role of the type III effector inventory of Pseudomonas syringae pv. phaseolicola 1448a in interaction with the plant. J Bacteriol. 2010;192(17):4474-88. doi:10.1128/ JB.00260-10

38. Pérez-Bueno ML, Pineda M, Díaz-Casado E, Barón M. Spatial and temporal dynamics of primary and secondary metabolism in Phaseolus vulgaris challenged by Pseudomonas syringae. Physiol Plant. 2015;153(1):161-74. doi:10.1111/ppl.12237.

39. Berge O, Monteil CL, Bartoli C, Chandeysson C, Guilbaud C, Sands DC, et al. A user's guide to a data base of the diversity of Pseudomonas syringae and its application to classifying strains in this phylogenetic complex. PLoS One. 2014;9(9), e105547. doi:10.1371/journal.pone.0105547.
40. Matas IM, Pérez-Martínez I, Quesada JM, Rodríguez-Herva JJ, Penyalver R, Ramos C. Pseudomonas savastanoi pv. savastanoi contains two iaal paralogs, one of which exhibits a variable number of a trinucleotide (TAC) tandem repeat. Appl Environ Microbiol. 2009;75(4):1030-5. doi:10.1128/ AEM.01572-08

41. Putman M, van Veen HW, Konings WN. Molecular properties of bacterial multidrug transporters. Microbiol Mol Biol Rev. 2000;64(4):672-93.

42. Garcillán-Barcia MP, de la Cruz F. Distribution of IS91 family insertion sequences in bacterial genomes: evolutionary implications. FEMS Microbiol Ecol. 2002;42(2):303-13. doi:10.1111/j.1574-6941.2002.tb01020.x.

43. Soby $S$, Kirkpatrick B, Kosuge T. Characterization of high-frequency deletions in the iaa-containing plasmid, pIAA2, of Pseudomonas syringae pv. savastanoi. Plasmid. 1994;31(1):21-30. doi:10.1006/plas.1994.1003.

44. Lane WJ, Darst SA. The structural basis for promoter -35 element recognition by the group IV $\sigma$ factors. PLoS Biol. 2006;4(9), e269. doi:10.1371/journal.pbio.0040269.

45. Enz S, Mahren S, Menzel C, Braun V. Analysis of the ferric citrate transport gene promoter of Escherichia coli. J Bacteriol. 2003;185(7):2387-91. doi:10.1128/jb.185.7.2387-2391.2003.

46. Lisser S, Margalit H. Compilation of E.coli mRNA promoter sequences. Nucleic Acids Res. 1993;21(7):1507-16. doi:10.1093/nar/21.7.1507.

47. Domínguez-Cuevas P, Marqués S. Compiling sigma-70-dependent promoters. In: Ramos J-L, editor. Virulence and gene regulation. US: Springer; 2004. p. 319-43.

48. Cumbie JS, Kimbrel JA, Di Y, Schafer DW, Wilhelm $\sqcup$, Fox SE, et al. GENE-counter: a computational pipeline for the analysis of RNA-Seq data for gene expression differences. PLoS One. 2011;6(10), e25279. doi:10.1371/journal.pone.0025279.

49. Almeida NF, Yan S, Lindeberg M, Studholme DJ, Schneider DJ, Condon B, et al. A draft genome sequence of Pseudomonas syringae pv. tomato T1 reveals a Type III effector repertoire significantly divergent from that of Pseudomonas syringae pv. tomato DC3000. Mol Plant Microbe Interact. 2009;22(1):52-62.

50. Naville M, Ghuillot-Gaudeffroy A, Marchais A, Gautheret D. ARNold: a web tool for the prediction of Rho-independent transcription terminators. RNA Biol. 2011;8(1):11-3.

51. Sreedharan A, Penaloza-Vazquez A, Kunkel BN, Bender CL. CorR regulates multiple components of virulence in Pseudomonas syringae pv. tomato DC3000. Mol Plant Microbe Interact. 2006;19(7):768-79. doi:10.1094/MPMI-19-0768.

52. Pel MJ, van Dijken AJ, Bardoel BW, Seidl MF, van der Ent S, van Strijp JA, et al. Pseudomonas syringae evades host immunity by degrading flagellin monomers with alkaline protease AprA. Mol Plant Microbe Interact. 2014;27(7):603-10. doi:10.1094/MPMI-02-14-0032-R

53. Macho AP, Zumaquero A, Ortíz-Martín I, Beuzón CR. Competitive index in mixed infections: a sensitive and accurate assay for the genetic analysis of Pseudomonas syringae-plant interactions. Mol Plant Pathol. 2007:8(4):437-50. doi:10.1111/j.1364-3703.2007.00404.x.

54. Wei CF, Kvitko BH, Shimizu R, Crabill E, Alfano JR, Lin NC, et al. A Pseudomonas syringae pv. tomato DC3000 mutant lacking the type III effector HopQ1-1 is able to cause disease in the model plant Nicotiana benthamiana. Plant J. 2007;51(1):32-46. doi:10.1111/j.1365-313X.2007.03126.x.

55. Barón M, Flexas J, DeLucia EH. Photosynthetic responses to biotic stress terrestrial photosynthesis in a changing environment. Cambridge University Press. 2012.

56. Swarbrick PJ, Schulze-Lefert P, Scholes JD. Metabolic consequences of susceptibility and resistance (race-specific and broad-spectrum) in barley leaves challenged with powdery mildew. Plant Cell Environ. 2006;29(6):1061-76. doi:10.1111/j.1365-3040.2005.01472.x.

57. Pineda M, Gáspár L, Morales F, Szigeti Z, Barón M. Multicolor fluorescence imaging of leaves - a useful tool for visualizing systemic viral infections in plantst. Photochem Photobiol. 2008;84(5):1048-60. doi:10.1111/j.1751-1097.2008.00357.x.

58. Cerovic ZG, Ounis A, Cartelat A, Latouche G, Goulas Y, Meyer S, et al. The use of chlorophyll fluorescence excitation spectra for the non-destructive in situ assessment of UV-absorbing compounds in leaves. Plant Cell Environ. 2002;25(12):1663-76. doi:10.1046/j.1365-3040.2002.00942.x.

59. Takács Z, Lichtenthaler HK, Tuba Z. Fluorescence emission spectra of desiccation-tolerant cryptogamic plants during a rehydration-desiccation cycle. J Plant Physiol. 2000;156(3):375-9.

60. Chaerle L, Lenk S, Hagenbeek D, Buschmann C, Van Der Straeten D. Multicolor fluorescence imaging for early detection of the hypersensitive reaction to tobacco mosaic virus. J Plant Physiol. 2007;164(3):253-62. 
61. Vargas P, Farias GA, Nogales J, Prada H, Carvajal V, Barón M, et al. Plant flavonoids target Pseudomonas syringae pv. tomato DC3000 flagella and type III secretion system. Environ Microbiol Rep. 2013;5(6):841-50. doi:10.1111/1758-2229.12086

62. Gardan L, Shafik H, Belouin S, Broch R, Grimont F, Grimont PAD. DNA relatedness among the pathovars of Pseudomonas syringae and description of Pseudomonas tremae sp. nov. and Pseudomonas cannabina sp. nov. (ex Sutic and Dowson 1959). Int J Syst Bacteriol. 1999:49:469-78.

63. Sarkar SF, Guttman DS. Evolution of the core genome of Pseudomonas syringae, a highly clonal, endemic plant pathogen. Appl Environ Microbiol. 2004;70(4):1999-2012.

64. Studholme DJ. Application of high-throughput genome sequencing to intrapathovar variation in Pseudomonas syringae. Mol Plant Pathol. 2011;12(8):829-38. doi:10.1111/j.1364-3703.2011.00713.x.

65. Rodríguez-Palenzuela P, Matas IM, Murillo J, López-Solanilla E, Bardaji L, Pérez-Martínez l, et al. Annotation and overview of the Pseudomonas savastanoi pv. savastanoi NCPPB 3335 draft genome reveals the virulence gene complement of a tumour-inducing pathogen of woody hosts. Environ Microbiol. 2010;12(6):1604-20. doi:10.1111/j.1462-2920.2010.02207.x.

66. Hanahan D. Studies on transformation of Escherichia coli with plasmids. J Mol Biol. 1983;166(4):557-80.

67. Ortíz-Martín I, Thwaites R, Macho AP, Mansfield JW, Beuzón CR. Positive regulation of the Hrp type III secretion system in Pseudomonas syringae pv. phaseolicola. Mol Plant Microbe Interact. 2010;23(5):665-81. doi:10.1094/ MPMI-23-5-0665

68. Blatny JM, Brautaset T, Winther-Larsen HC, Karunakaran P, Valla S. Improved broad-host-range RK2 vectors useful for high and low regulated gene expression levels in gram-negative bacteria. Plasmid. 1997;38(1):35-51. doi:10.1006/plas.1997.1294.

\section{Submit your next manuscript to BioMed Central and take full advantage of:}

- Convenient online submission

- Thorough peer review

- No space constraints or color figure charges

- Immediate publication on acceptance

- Inclusion in PubMed, CAS, Scopus and Google Scholar

- Research which is freely available for redistribution 